Tohoku J. exp. Med., 1980, 132, 389-395

\title{
Measurement of Triiodothyronine in Urine
}

\author{
Katsumi Yoshida, Toshiro Sakurada, Nobuko KaIse, \\ Makiko Yamamoto, Kazuo Kaise, Shintaro SaIto and \\ KaORU Yoshinaga
}

The Second Department of Internal Medicine, Tohoku University School of Medicine, Sendai 980

\begin{abstract}
Yoshida, K., Sakurada, T., Kaise, N., Yamamoto, M., Kaise, K., SaIto, S. and Yoshinaga, K. Measurement of Triiodothyronine in Urine. Tohoku J. exp. Med., 1980, 132 (4), 389-395 — A radioimmunoassay procedure to measure triiodothyronine $\left(\mathrm{T}_{3}\right)$ in unextracted urine is described. One hundred $\mu \mathrm{l}$ of $\mathrm{T}_{3}$ standards or samples were incubated with $100 \mu \mathrm{l}$ of $\mathrm{T}_{3}$ antiserum $(1: 40,000), 100 \mu \mathrm{l}$ of tracer ${ }^{125} \mathrm{I}_{-} \mathrm{T}_{3}$ and $700 \mu \mathrm{l}$ of $0.05 \mathrm{M}$ borate buffer, $\mathrm{pH} 8.6$. Separation of free from bound antigen was achieved by dextran coated charcoal. The cross-reaction of $L-T_{3}$ with $L-T_{4}$ in this assay system was less than $0.2 \%$. Dilution of high $\mathrm{T}_{3}$ urine was parallel to the standard curve. Recovery was $101 \pm 8$ $\%$. Coefficients of variation were $3-8 \%$ within each assay and $13 \%$ between assays. Euthyroid subjects excreted $0.81 \pm 0.39 \mu \mathrm{g}$ (mean \pm s.D.) in $24 \mathrm{hr}$. Similar values were obtained in pregnant women, euthyroid patients with chronic thyroiditis, and a patient with thyroxine-binding globulin deficiency. Excretion of urinary $\mathrm{T}_{3}$ was high $(7.48 \pm 3.32 \mu \mathrm{g} / 24 \mathrm{~h})$ in patients with hyperthyroidism, and low $(0.14 \pm 0.15 \mu \mathrm{g} / 24 \mathrm{hr})$ in patients with hypothyroidism. Urinary $\mathrm{T}_{3}$ excretion was almost undetectable in terminal renal failure. Positive correlations were found between urinary $\mathrm{T}_{3}$ and serum total $\mathrm{T}_{3}(r=0.89)$ and especially serum free $T_{3}(r=0.97)$. A positive correlation was also found between urinary $T_{3}$ and creatinine clearance $(r=0.63)$. Mean urinary clearance of $T_{3}\left(C_{T_{3}}=\right.$ Urinary $T_{3}$ excretion/serum free $T_{3}$ was $166 \mathrm{ml} / \mathrm{min}$ and was significantly higher than their mean creatinine clearance $(110 \mathrm{ml} / \mathrm{min})$. The measurement of $T_{3}$ in urine is reliable and easy to perform, and may allow a new approach to the understanding of thyroid hormone metabolism. —— triodothyronine in urine; radioimmunoassay; free thyroid hormone
\end{abstract}

The free thyroid hormone is available to the tissue to induce the effects on the cell metabolism (Ingbar and Freinkel 1960; Robbins and Rall 1960). Therefore, the concentration of the free thyroid hormone acts as an important determinant of the metabolic state. Since only a small percentage $(0.2 \%-0.3 \%)$ of circulating triiodothyronine $\left(\mathrm{T}_{3}\right)$ is present in the free form, the measurement of free $\mathrm{T}_{3}$ is too complicated to be applied as a routine test (Sterling and Hegedus 1962; Schussler and Plager 1967; Lee et al. 1964). It is considered that the urinary concentration of $T_{3}$ might change in accordance with the level of free $T_{3}$ in serum. In the present paper, a method of radioimmunoassay (RIA) for urinary $\mathrm{T}_{3}$ is described.

Received for publication, November 8, 1979. 


\title{
Materials and Methods
}

Radioimmunoassay for $T_{3}$ in urine

Urinary $\mathrm{T}_{3}$ was measured by RIA on unextracted urine according to the RIA method for serum $T_{3}$ described previously (Sakurada et al. 1973). Specific antiserum against $T_{3}$ was raised by immunizing the rabbits with $\mathrm{T}_{3}$-methylester hydrochloride-bovine serum albumin (BSA) conjugate in complete Freund's adjuvant.

As shown in Fig. 1, $100 \mu \mathrm{l}$ of undiluted urine samples or $\mathrm{T}_{3}$ standards were incubated with $100 \mu$ l of $\mathrm{T}_{3}$ antiserum $(1: 40,000), 100 \mu \mathrm{l}$ of tracer ${ }^{125} \mathrm{I}-\mathrm{T}_{3}$ and $700 \mu \mathrm{l}$ of buffer overnight $(16-20 \mathrm{hr})$ at $4^{\circ} \mathrm{C}$. The buffer used in the assay system was $0.05 \mathrm{M}$ borate buffer, $\mathrm{pH} 8.6$, containing $0.5 \% \mathrm{BSA}$. Standard tubes were received equivalent volume $(100 \mu \mathrm{l})$ of pooled hormone-free urine treated with 7 per cent activated charcoal. Separation of free from bound antigen was achieved by dextran-coated charcoal.

Serum $\mathrm{T}_{3}$ was measured by RIA previously described. Serum free fractions of $T_{3}$ were determined by a gel filtration technique (Sakurada et al. 1969), modified from that of Lee et al (1964).

\section{Determination of urinary $\mathrm{T}_{3}$}

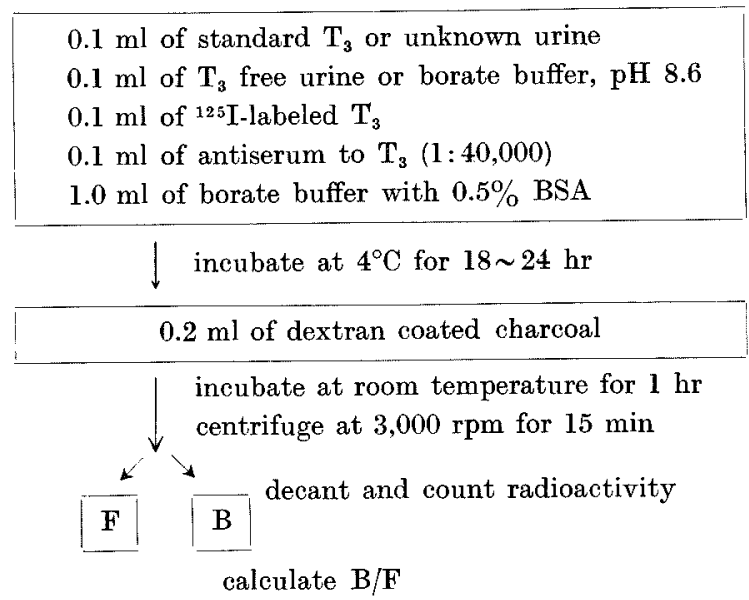

Fig. 1. Method of radioimmunoassay for $\mathbf{T}_{3}$ in urine.

\begin{abstract}
Materials
Urines were obtained from 45 euthyroid patients with no thyroid disorders and no proteinuira, 18 hyperthyroid patients, 14 hypothyroid patients, 7 euthyroid patients with chronic thyroiditis, 3 patients with anorexia nervosa, one patient with thyroxine bindingglobulin (TBG) deficiency, 6 patients with severe chronic renal failure (creatinine clearance, Cer, $<10 \mathrm{ml} / \mathrm{min}$ ), and 11 subjects in the third trimester of pregnancy. Urine was collected from each subject over a period of $24 \mathrm{hr}$. The total volume was measured and an aliquot was stored frozen at $-20^{\circ} \mathrm{C}$.
\end{abstract}

\section{Validation}

Fig. 2 shows the typical curvilineal standard curve and dilution curve for $\mathrm{T}_{3}$. Dilution curve was parallel to the standard curve. Cross reaction of $\mathrm{L}-\mathrm{T}_{3}$ with $\mathrm{L}-\mathrm{T}_{4}$ in this assay system was less than $0.2 \%$. Various amounts of $\mathrm{L}-\mathrm{T}_{3}$ were added to urine and recovery was $101 \pm 8 \%$ (mean \pm s.D.). Coefficients of variation were $3-8 \%$ within each assay and $13 \%$ between assays. Correction of urinary $\mathrm{pH}$ was unnecessary, since the urinary $\mathrm{pH}$ ranging between 4 and 11 did not affect the $\mathrm{T}_{3}$ determination by RLA. 


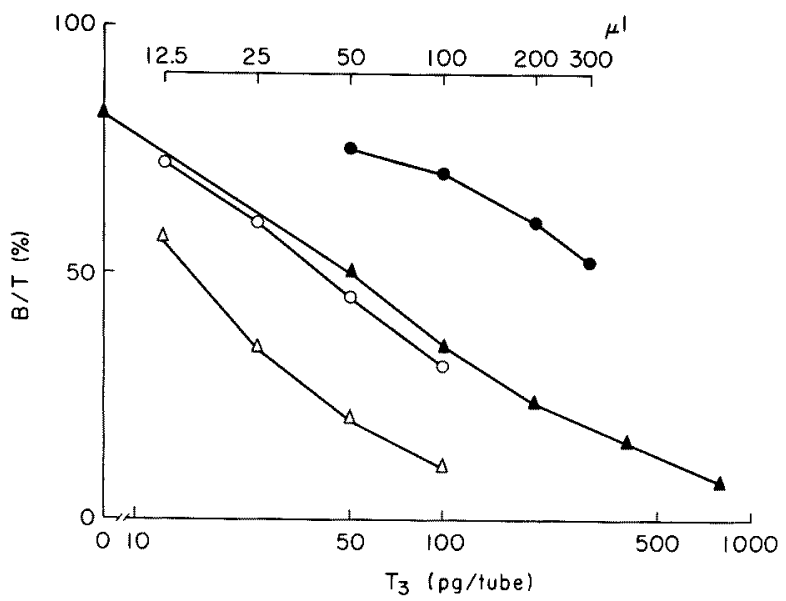

Fig. 2. Standard curve and dilution curve for radioimmunoassay of $T_{3}$ in urine. $\Delta, T_{3}$ standard curve; $\circ$, euthyroid; $\Delta$, hyperthyroid; $\bullet$, hypothyroid.

\section{Calculations}

Serum free $T_{3}$ concentration was calculated as the product of total $T_{3}$ and $\%$ free $T_{3}$ by gel filtration. Clearances of free $\mathrm{T}_{3}\left(\mathrm{CT}_{3}\right)$ were calculated as follows:

$$
\mathrm{CT}_{3}=\frac{\text { Urine } \mathrm{T}_{3}(\mathrm{ng} / 24 \mathrm{~h})}{\text { Serum free } \mathrm{T}_{3}(\mathrm{ng} / \mathrm{ml}) \times 1,440}(\mathrm{ml} / \mathrm{min})
$$

\section{Results}

\section{Urinary $T_{3}$ concentrations}

Excretion of urinary $T_{3}$ in 45 euthyroid patients was $0.81 \pm 0.39 \mu \mathrm{g} / \mathrm{day}$ (mean \pm s.D.), ranging from 0.3 to $1.96 \mu \mathrm{g} /$ day. The urinary $\mathrm{T}_{3}$ in a patient with TBG deficiency was normal $(0.9 \mu \mathrm{g} /$ day $)$. The mean urinary $\mathrm{T}_{3}$ in 18 hyperthyroid patients was $7.48 \pm 3.32 \mu \mathrm{g} /$ day (range, $2.88-14.6 \mu \mathrm{g} /$ day), a value significantly higher than that observed in euthyroid subjects (unpaired $t$-test, $p<0.001$ ).

The mean urinary $\mathrm{T}_{3}$ in 14 hypothyroid patients was $0.14 \pm 0.15 \mu \mathrm{g} /$ day (range, $0-0.54 \mu \mathrm{g} / \mathrm{day}$ ), a value significantly lower than the corresponding normal value. $(p<0.001)$.

The mean urinany $\mathrm{T}_{3}$ in 7 euthyroid patients with chronic thyroiditis was 0.54 $\pm 0.21 \mu \mathrm{g} /$ day, a value slightly lower than the corresponding normal value, but the difference was not statistically significant.

Mean urinay $\mathrm{T}_{3}$ in the 11 pregnant women was $1.06 \pm 0.39 \mu \mathrm{g} / \mathrm{day}$, a value slightly higher than that observed in euthyroid patients, but the difference was not significant.

All three patients with anorexia nervosa had low urinary $\mathrm{T}_{3}$ levels, and all patients with chronic renal failure had very low urinary $\mathrm{T}_{\mathbf{3}}$ levels (Fig. 3). 


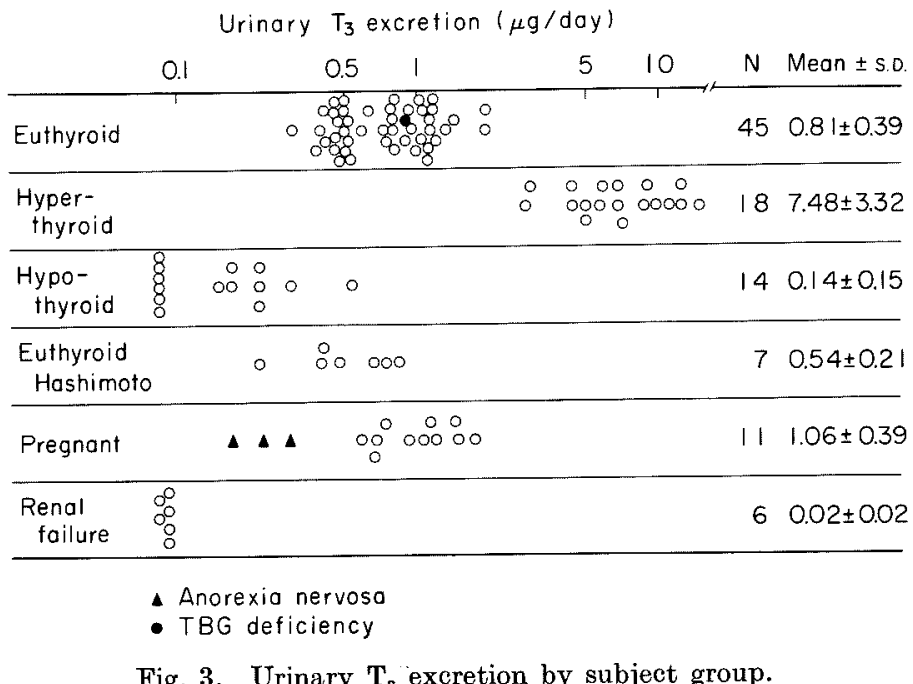

Fig. 3. Urinary $\mathbf{T}_{3}$ excretion by subject group.

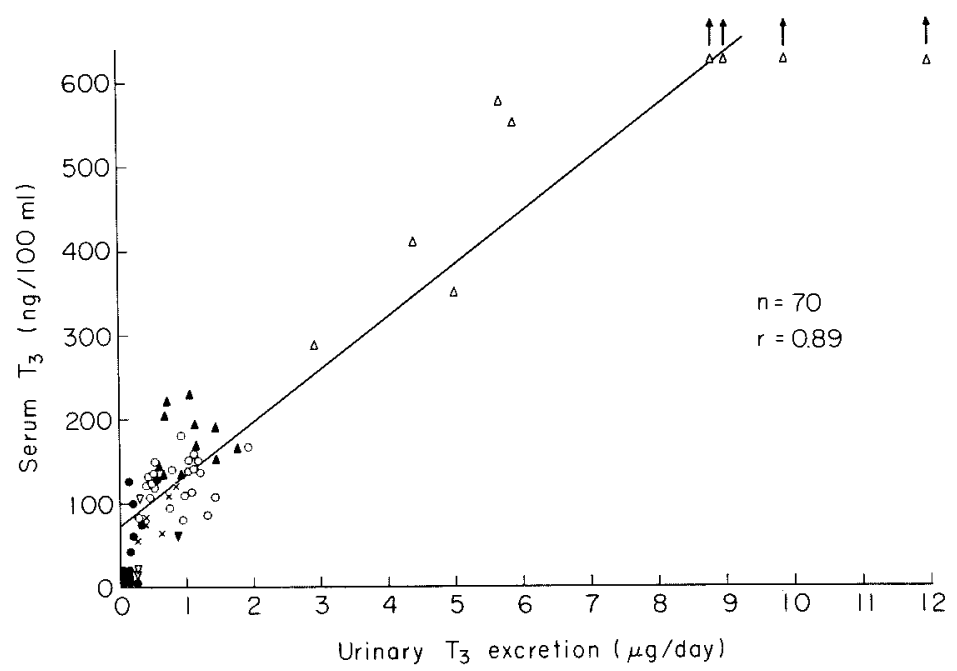

Fig. 4. Correlation between serum $\mathrm{T}_{3}$ and urinary $\mathrm{T}_{3}$ excretion. o, euthyroid; $\Delta$, hyperthyroid; $\bullet$, hypothyroid; $\times$, euthyroid Hashimoto; $\nabla$, anorexia nervosa; $\Delta$, pregnant; v, TBG deficiency.

\section{Correlation of urinary $T_{3}$ with serum total and free $T_{3}$}

As shown in Fig. 4, a positive correlation between urinary $\mathbf{T}_{\mathbf{3}}$ and serum total $\mathrm{T}_{3}$ was obtained for the entire group of 70 samples studied. However, in pregnant women, urinary $\mathrm{T}_{3}$ was low as compared with serum $\mathrm{T}_{3}$. And, in a patient with TBG deficiency, urinany $\mathrm{T}_{3}$ was high as compared with serum $\mathrm{T}_{3}$.

An excellent positive correlation $(r=0.97)$ was observed between urinary $\mathrm{T}_{3}$ and serum free $\mathrm{T}_{\mathbf{3}}$ (Fig. 5). 


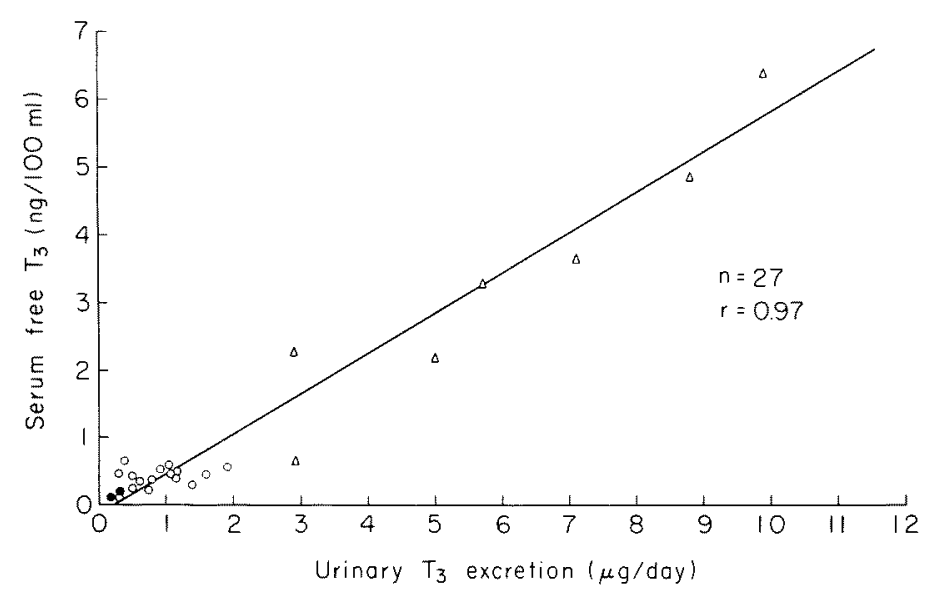

Fig. 5. Correlation between serum free $\mathrm{T}_{3}$ and urinary $\mathrm{T}_{3}$ excretion. $\circ$, euthyroid; $\Delta$, hyperthyroid; $\bullet$, hypothyroid.

Correlation between urinary $T_{3}$ and $C$ cr.

A positive correlation was also found between urinary $\mathrm{T}_{3}$ and $\operatorname{Cer}(r=0.63$, $p<0.01$ ). Urinary $\mathrm{T}_{3}$ was significantly reduced in chronic renal failure (Fig. 6).

Renal clearance of free serum $T_{3}$

The mean renal clearance rate of free $\mathrm{T}_{3}$ in 15 euthyroid patients was $174 \mathrm{ml} /$ min, and the range was wide from 42 to $366 \mathrm{ml} / \mathrm{min}$ (Fig. 7). The mean $\mathrm{T}_{3}$ clearance rates in 10 hyperthyroid patients and in 2 hypothyroid patients were 166

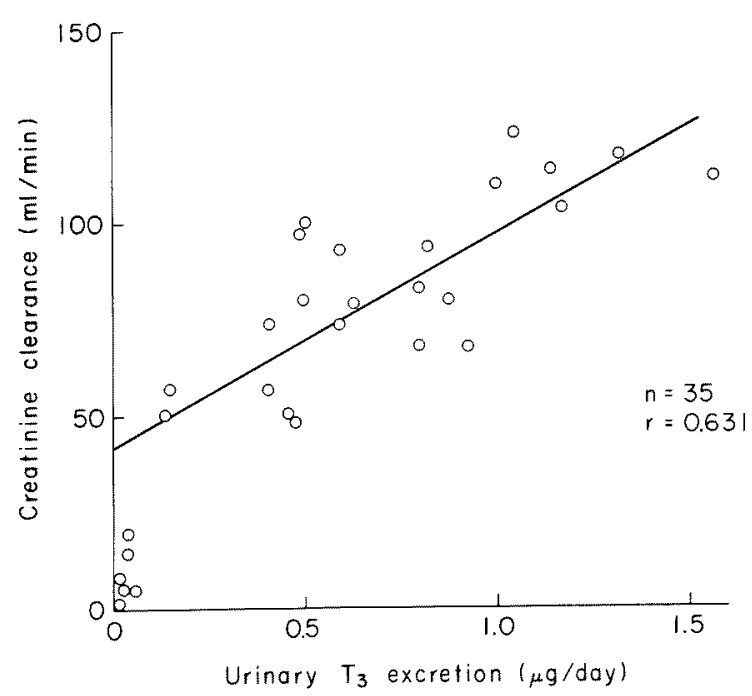

Fig. 6. Correlation between urinary $\mathrm{T}_{3}$ and creatinine clearance. 


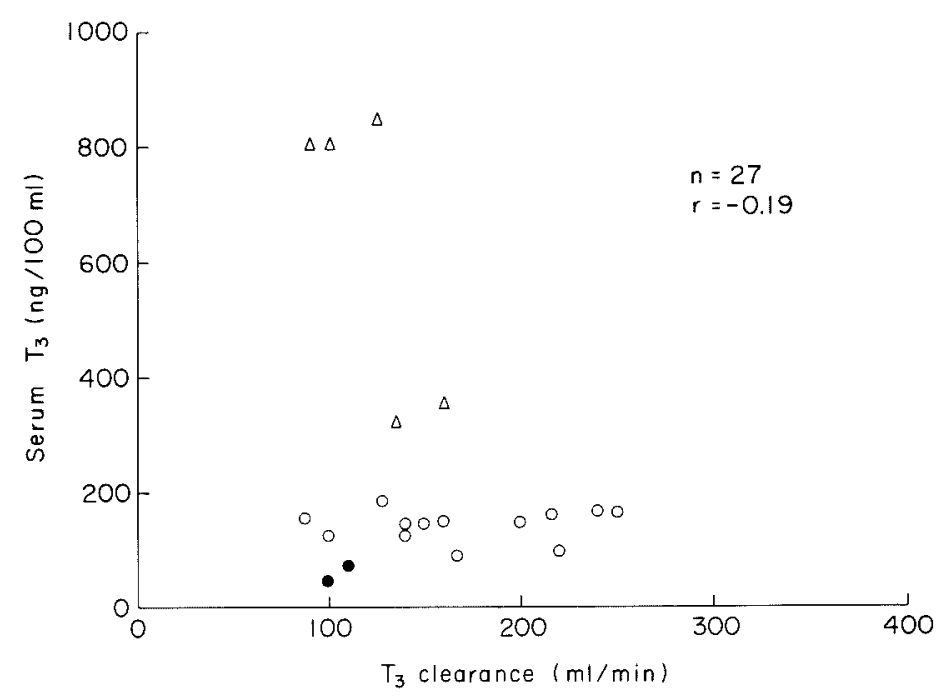

Fig. 7. Correlation between urinary $T_{3}$ clearance and serum $T_{3}$. $\quad 0$, euthyroid; $\Delta$, hyperthyroid; $\bullet$, hypothyroid.

$\mathrm{ml} / \mathrm{min}$ and $106 \mathrm{ml} / \mathrm{min}$, respectively. As a whole, the mean $\mathrm{T}_{3}$ clearance rate was $166 \mathrm{ml} / \mathrm{min}$ and was significantly higher than their mean Cer $(110 \mathrm{ml} / \mathrm{min})(p<$ $0.05)$.

\section{Discussion}

Since Chan and coworkers (1972) have reported the measurement of urinary $\mathrm{T}_{3}$ a number of studies of urinary $\mathrm{T}_{3}$ have been published (Burke et al. 1972; Hüfner and Hesch 1973; Gaitan et al. 1975; Rogowski et al. 1978). In the first study of urinary $\mathrm{T}_{\mathbf{3}}$ by Chan et al., urine was acidified to $\mathrm{pH} 4.0$ and urinary $\mathrm{T}_{\mathbf{3}}$ was extracted with ethyl acetate prior to the RIA. Many subsequent papers pointed out that when $T_{3}$ was assayed on unextracted urine, the urinary $T_{3}$ values were about one-third of those reported by Chan et al., and suggested that the extraction procedure might induce the hydrolysis of $\mathrm{T}_{\mathbf{3}}$ conjugates.

We also measured urinary $\mathrm{T}_{3}$ by RIA on unextracted urine and the obtained result in euthyroid controls was of the same order as those of several of the studies mentioned above, about one-third of those by Chan et al. We have not established whether $\mathrm{T}_{3}$ conjugates or metabolites are measured in our RIA system. But, using enzymatic and acid hydrolysis, Burke et al. (1972) and Gaitan et al. (1975) reported that the conjugate was not measured in their system, because urinary $\mathrm{T}_{3}$ value increased after hydrolysis. Our normal value is close to those of Burke et al. and Gaitan et al. Therefore, the conjugate might not be measured in our system either.

As previously reported (Sakurada et al. 1973), our antisera against $\mathrm{T}_{\mathbf{3}}$ were specific, but they cross-react slightly with $\mathrm{T}_{\mathbf{3}}$ derivatives such as triiodothyroacetic 
acid, triiodothyropropionic acid and so on. Therefore, there is still a possibility that these metabolites were also measured in the present RIA system, though the serum values are reported to be very low (Nakamura et al. 1978).

Anyway, excellent correlations were found between urinary $T_{3}$ and serum $T_{3}$, and especially serum free $\mathrm{T}_{3}$. Furthermore, urinary $\mathrm{T}_{3}$ was not influenced by changes in circulating TBG concentration, since the normal values were found in pregnancy with high serum TBG as well as in TBG deficiency. These results indicate that urinary $T_{3}$ values reflect serum free $T_{3}$ concentrations.

The mean $\mathrm{T}_{3}$ clearance rate was significantly higher than creatinine clearance. This might be the result of tubular excretion of $T_{3}$, perhaps $T_{3}$ being produced in this tissue from $\mathbf{T}_{4}$ by deiodination.

The development of a simple and reliable assay for $T_{3}$ in urine will permit further studies on $\mathrm{T}_{3}$ metabolism.

\section{References}

1) Burke, C.W., Shakespear, R.A. \& Fraser, T.R. (1972) Measurement of thyroxine and triiodothyronine in human urine. Lancet, 2, 1177-1179.

2) Chan, V., Landon, J., Besser, G.M. \& Ekins, R.P. (1972) Urinary triodothyronine excretion as index of thyroid function. Lancet, 2, 253-256.

3) Gaitan, E.J., Wahner, W.H., Gorman, A.C. \& Jiang, N. (1975) Measurement of triiodothyronine in unextracted urine. J. Lab. clin. Med., 86, 538-546.

4) Hüfner, M. \& Hesch, R.D. (1973) Triiodothyronine determinations in urine. Lancet, $1,101-102$.

5) Ingbar, S.H. \& Freinkel, N. (1960) Regulation of the peripheral metabolism of the thyroid hormones. Recet. Progr. Hormone Res., 16, 353-403.

6) Lee, N.D., Henry, R.J. \& Golub, O.J. (1964) Determination of the free thyroxine content of serum. J. clin. Endocr., 24, 486-495.

7) Nakamura, Y., Chopra, I.J. \& Solomon, D.H. (1978) An assessment of the concentration of acetic acid and propionic acid derivatives of 3,5,3'-triodothyronine in human serum. J. clin. Endocr., 46, 91-97.

8) Robbins, J. \& Rall, J.E. (1960) Proteins associated with the thyroid hormones. Physiol. Rev., 40, 415-498.

9) Rogowski, P., Siersbok-Nielsen, K. \& Molholm Hansen, J. (1978) Urinary excretion of thyroxine and triiodothyronine in different thyroid function states in man. Acta Endocr., 87, 525-534.

10) Sakurada, T., Saito, S., Inagaki, K., Takayama, S. \& Torikai, T. (1969) Quantitative determination of total and free triiodothyronine and thyroxine. Tohoku J. exp. Med., 99, 179-188.

11) Sakurada, T., Saito, S., Yamaguchi, T., Yamamoto, M., Demura, R., Demura, H., Fukuchi, S., Yoshida, K. \& Torikai, T. (1973) Radioimmunoassay of triiodothyronine. Tohoku J. exp. Med., 110, 329-340.

12) Schussler, G.C. \& Plager, J.E. (1967) Effect of preliminary purification of ${ }^{131}$ Ithyroxine on the determination of free thyroxine in serum. J. clin. Endocr., 27, 242250.

13) Sterling, K. \& Hegedus, A. (1962) Measurement of free thyroxine concentration in human serum. J. clin. Invest., 41, 1031-1040. 